\title{
Rethinking the Role of International Civil Service on Sustainable Development in Africa: Issues, Challenges and the Way Forward
}

\author{
C.J Igbokwe-Ibeto (PhD) \\ Department of Public Administration \\ Faculty of Management Sciences \\ Nnamdi Azikiwe University, Awka \\ E-mail: c.igbokwe-ibeto@unizik.edu.ng; \\ I.L Nnaji $(\mathrm{PhD})$ \\ Department of Public Administration \\ Faculty of Management Sciences \\ Nnamdi Azikiwe University, Awka \\ E-mail: ifeomannaji18@gmail.com
}

Received: Sep. 24, 2019 Accepted: Oct. 21, 2019 Online published: Nov. 7, 2019

doi:10.5296/jpag.v9i4.15708～URL: https://doi.org/10.5296/jpag.v9i4.15708

\begin{abstract}
International civil servants are expected to provide leadership that could translate into practical gains for all human societies across the globe. They are to use their creative talents, knowledge and experience to bring these goals to pass in the life of the people of the world, particularly in developing countries. While they have embraced these goals, the extent to which they have accomplished them is still a matter of debate. Therefore, within the framework of structural-agency theory, the paper examined international civil service (ICS) and sustainable development in Africa with the aim of identifying issues, challenges and the way forward. The article employed the methods of qualitative research design as well as exploratory and descriptive perspectives. The researchers also consulted different sources to ensure quality of the article. Subsequently, relevant sources of this research were fairly and professionally scrutinised, understood and tested with the available literature for the purpose
\end{abstract}


of the research. Inter alia, it included scan-reading, comprehensive and critical reading and writing down ideas. Authoritative scholarly sources were reviewed, during a desktop study. The aim was to identify the relevant publications and apply them in the research. This article argues that international civil servants are expected as a philosophy to pursue the corporate interests of the people rather than their own personal or group interests. This is why they are fondly called servants of the state and the world community respectively. However, it appears personal and group interests have found its way into common interest. It concludes that if the ICS is to make any impact on the campaign for rapid socio-economic development of the world, the ICSs need to be proactive and interventionist in order to arrest the increasing decline in socio-economic and political development across the globe and most especially in Africa.

Keywords: development, civil service, international, sustainability, globalization

\section{Introduction}

The world has become a global village with goods, services and human beings moving across natural and artificial boundaries. International organizations are some of the major players in this globalised. They carry enormous influence that some national governments are afraid to give them the latitude to operate within their national boundaries by seeking to control their activities. Some of these activities and actions are carried out not minding their consequences for human welfare, economic and environmental safety. Yet, the world requires different types of International Organizations (1Os) to reach out to people and address concerns that confront them. International organizations therefore, have come to stay. How they can be managed should be the issue. Equally important to the realization of a better global system, is the key roles international civil servants (ICSs) play in these organizations.

To avoid chaos and conflict of interests, international cooperation on all fronts is necessary. Thus, there is need for regulatory bodies to monitor and regulate relations among individuals, groups and nations in the international system. Such organization of activities require coordination to enable their various actors achieve set goals. Statesmen of the international community have for long realized this imperative which explained the formation of the League of Nations after the First World War. However, this effort could not create and maintain world peace. This led to another effort that culminated in the formation of the United Nations in 1945, to play the role of a supra-national government for the peace and stability of the world.

The United Nations (UN) is one international organisation with influence on world administration and politics. It has its own structures and institutions which are not too different from the national civil service. Its head, the Secretary General of the UN is the number one civil servant in the world. He has enormous influence on the world administration and this influence can be brought to bear on global cooperation to bring about a world where humanity will be better served. For a long time, this aspect of intellectual discourse in international administration and politics was neglected. Those who work in these international organizations were not given the attention and credit they deserve. This study aims to address a dual research question. How do the international bureaucrats help achieve 
these lofty ideas? In the era of globalization, can ICSs engineer a level playing field for both developing and developed countries to cooperate for the good of their people in their respective spheres?

\section{Methodology}

This article employed the methods of qualitative research design as well as exploratory and descriptive perspectives. The researchers also consulted different sources to ensure quality of the article. Subsequently, relevant sources of this research were fairly and professionally scrutinised, understood and tested with the available literature for the purpose of the research. Inter alia, it included scan-reading, comprehensive and critical reading and writing down ideas. Authoritative scholarly sources were reviewed, during a desktop study. The aim was to identify the relevant publications and apply them in the research.

\section{Conceptual and Theoretical Underpinning}

International civil service as a concept has attracted several definitions. But unlike other concepts, it has not generated much controversy as to its actual meaning. According to Graham and Jordan in (Akhakkpe, 2014), the term international civil service refers to those individuals in professional positions at the United Nations headquarters and their National Economic Commissions as well as the secretariats of United Nations Conference on Trade and Agreement (UNCTAD), United Nations Industrial Development Organisation (UNIDO) and UNEP. Like national governments of member states, the UN needs an elite corps of civil servants to help formulate and implement policies or laws made by the UN General Assembly and Security Council.

The ICS is made up of men and women employed in a civil capacity in the government of the $\mathrm{UN}$ and its numerous agencies and programmes with fixed tenure of office. The number one bureaucrat or civil servant in the world is the Secretary General of the UN who is usually elected from among member states of the organization. Apart from maintaining world peace, bureaucrats under the aegis of the UN are also enjoined to promote the welfare and well-being of peoples in different countries of the world through promotion of qualitative education, fight against deadly diseases, facilitation of clean environment and other world threatening issues and conditions (Akhakpe, 2014; Anazodo, 2012).

Sustainable development is a concept that has attracted different views and characterization. But unlike some disputed concepts, there appears to be a consensus among development theorists that the concept is all about uplifting the material and physical conditions of man on the surface of the earth. Thus, any definition of sustainable development that fails to priorities the human factor is not likely to be heuristic or popular among its beneficiaries. It is against this backdrop that Ibeanu (2008) conceives sustainable development as a "holistic process and no aspect can be isolated for study in the manner modernization (perspective) suggests". In this process, man is the centerpiece who achieves sustainable development by interacting with a given bio-physical environment. Nnoli (2001) attempts an eclectic view of the concept of sustainable development as: a theoretical phenomenon in which the individual and society interact with their physical, biological and inter-human environments transforming them for 
their own betterment and that of humanity at large and being transformed in the process. The lesson learned and experiences acquired in this process are passed on to future generations, enabling them to improve their capacities to make further valuable change in their inter-human relations and their ability to transform nature.

Development is brought about by man interacting with the bio-physical environment and fellow human beings. In this process, lessons are learnt and these are passed on to the next generation. In this process socio-economic transformation of man and society takes place. It can therefore, be argued that development is not something anybody bequeaths to another. Man has always demonstrated abilities and capabilities to increase their capacity to deal with challenges arising from the environment. For Igbokwe-Ibeto (2018); Dibie and Dibie (2015), human societies have always shown their capabilities to develop through improving their capacities to deal with their biological and physical environments through understanding nature and use of such knowledge to create tools and organize work environment.

Once these processes of development are embraced, they need to be engaged to continually maintain changes going on in such society. Development in all areas of human lives should be sustained for it effects to be optimally domesticated in the life of man and the environment he leaves in. Therefore, sustainable development as a concept can be seen as processes of social change that meet the demands of the present without blocking those of the future generation to achieve their goals. Anazodo, Igbokwe-Ibeto, Osawe and Nkah (2014) notes that sustainable development is that development that meets our presents needs without compromising the ability of future generation to meet their own needs. Activities and actions of people to meet their needs should not block others from carrying out their developmental drive. The United Nations (2005) has come up with three key factors in sustainable development. These are: economic development, political development and environmental development. It went ahead to argue that these three elements should work together to achieve their desired goals. Also, sustainable development has a moral dimension to it in the sense that it requires enormous sense of responsibility from both its leaders and followers (Ayeni, 2010:76). These are issues international civil servants are expected to embrace, promote and protect across the world.

Peace and Watford in (Oyeshola, 2008) approach their conceptualization of sustainable development from the angle of environmental friendly activities, when they aver that: Sustainable development describes a process in which the natural resource base is not allowed to deteriorate It emphasizes the hitherto unappreciated role of the environmental quality and environmental inputs in the process of raising income and quality of life.

In contemporary times, these endeavors are prioritized in the process of achieving development. Hitherto, development was pursued in part with little or no linkage with its various parts or dimensions. Such linkage helps to sustain the processes of development. A cursory look at the concerns with development today will show that some of its key concerns directly or indirectly relate to developing countries particularly in sub-Sahara Africa. Thus, development that can be sustained in this part of the world according to Oyeshola (2008) will embrace the following: 
- Increases in real income for the poorest of the poor by eradicating poverty;

- Positive changes in the health and nutritional conditions of children and the young, mostly affected by preventable diseases;

- Improvement in education;

- Increased chances of accessing resources;

- Better and fairer distribution of income, to ensure that the average worker's pay or salary can take care of his nuclear family; and

- More basic freedoms, assured security of all citizens and more friendly and responsible relationship with the environmental system.

ICSs are expected to provide leadership in ensuring that these lofty ideas are translated into practical gains for all human societies across the globe. They are to use their creative talents, knowledge and experience to bring these goals to pass in the life of the people of the world, particularly in developing countries. While they have embraced these goals, the extent to which they have accomplished them is still a matter of debate.

As is with the tradition in social and management sciences, no one theoretical approach can adequately explain a social phenomenon or phenomena. Nonetheless, we need a platform on which to interrogate our subject of discourse. For this purpose and bearing in mind the constraint, this article finds the structural-agency theory useful here. According to Hay (1995), structure, be it in political or social context has an array of agents whose activities are product of intentional actions based on some knowledge of the structure that provides the setting for these actions. An agent can then be defined as a "person ... that exerts power or produces effects" (Hay 1995). It therefore, follows that power is closely bounded up with the idea of victory of agent over structure. Power in this context refers to the ability of an agency to influence or having effect upon the structure which itself set context and define the extent of possibilities of others (Hay, 1995).

Against this backdrop, we can come up with a relational understanding of both structure and agency in the sense that one man's agency is another man's structure. When juxtapose to international politics we can posit that the actions of head of States and governments and other world leaders produce the structures that constrain ICSs and other international bodies, the effects of actions of these agents also constrain the members of the international communities, either positively or negatively. This theory raises a lot of epistemological and ontological concerns that are still begging for answers. For example, as Hay (1995) again queried: to what extent can individual actions relate to their level of socialization and by extension structures over which they have little control over? How does one explain a particular political effect as being the consequence of the intentions and actions of the actors involved in them? Can an explanation ever be adequate? These are questions that might not be sufficiently answered.

\section{Principles of International Civil Service}

Those who articulated the idea of an international civil service put in place certain principles to guide its operations. Not surprising, these principles took the form of those found in the 
British civil service model because of the influence of its early founders. These principles according to Akhakpe, (2014) and Anazodo (2012) include:

- The principle of neutrality;

- The principle of impartiality;

- The principle of independence; and

- The principle of merit.

The principle of neutrality requires that employees of the UN secretariat known as ICS or bureaucrats shed whatever national interests of their individual countries they have and carry out their responsibilities only in the interest of the international organization. It is expected that in making decisions, ICS should ensure that they put aside any national sentiments they have and how such decisions might affect their respective countries. Perhaps, this will enable these employees to serve the organization and through it the members states, and by implication, the people of the member states. Closely related to the foregoing point is that staff of this organization should be independent in their service by not taking instructions from their national government or attempt to represent their national interest on any matter. It is left to be seen how practicable this is, in the context of today global system. These employees are first from a cultural background that may not be easy to put aside.

The second principle of impartiality demands that employees of the organization should see themselves as administrators not politicians. It is their responsibility to discharge faithfully decisions taken by the UN and avoid to be caught in the web of controversy. What this principle entails is provided in Graham and Jordan in (Anazodo, 2012:25):

Impartiality implies objectivity, lack of bias, tolerance, restraint-particularly when particular religious dispute or differences arise. The staff member's personal views and convictions remain inviolate but he has not the freedom of a private to 'take side' to enter a dispute as a partisan, or publicly to express his convictions on matters of a controversial nature, either singly or as a member of a group. Just as the practice of impartiality will strengthen the secretariat, repeated instances of impartiality or bias will do serious harm to the organization.

What comes out boldly to the fore in the above contention is that international civil servants or bureaucrats should be apolitical in the understanding that they will without any prompting implement any policy decisions reached by political bodies. It is difficult to substantiate this point knowing for a fact that man is a political animal and at any given point in time has a position on any subject matter.

The third principle is that of independence. Independence as used here means that the international secretariat of the UN and its agencies should be independent of national governments or group of States. This principle could be inferred in the first one explained. As earlier stated in the introduction, the job of international civil service constitutes a career with a considerable degree of job security. Perhaps, the essence of this principle is to allow 
employees of an IO pursue best practices in the interest of the organization without fear of removal from office on grounds of politics. This is likely to give the organization an international identity. To a large extent also, this will allow the ICS to demonstrate quality of mind, character and intellect. These qualities are likely to come from long period of service to an international organization.

Following from the above point is the fourth principle of a cadre of permanent career officials who are recruited on the basis of merit and who would put their loyalty to the organization over and above any other one. This implies that these international officials would not be under the control of any individual member states and by implication would carry out its duties impartially. Again, this is an ideal that may not be realizable. This belongs to what is described as the "traditional" concept of the ICS. It remains largely within the purview of theory or utopia because this principle can and indeed, is affected by so many factors such as increase in responsibilities, old structures that cannot shoulder new and complex responsibilities, among many more.

Has ICSs been able to use their career positions to achieve the "highest standards of efficiency, competence, and integrity? Opinions are that it has not (Anazodo, 2012). But empirical evidences are needed to buttress this assertion. One way to get at such proofs perhaps is from reviewing the state of global governance and development in Africa.

\section{The State of Global Governance and Sustainable Development in Africa}

It will be recalled that most states in sub-Sahara Africa (SSA) are artificial creations by virtue of their composite nature. This has serious implications for the way the bound to pursue the goal of development and nation-building. It also affects how the people see their states and its agency government in the whole enterprise of social change. Yet, Africa is one of the continents of the world well blessed and resourceful in terms of natural endowments. But these are potentials that are lying fallow or not adequately explored and exploited for the good of the continent and its people.

Also, in the western, politico-administrative system, after the people have paid their taxes, government is expected to better their material condition through judicious use of these taxes. However, all over Africa are tales of failed expectations of the people from their governments. Again Osaghae (1994) puts it graphically: when it comes to employment, provision of educational and health facilities, basic infrastructure including housing, public transportation, roads, electricity and water, and alleviation of poverty, the so-called capital-intensive public goods the people have had to rely almost entirely on the State. And in this task, the government has failed, for most part.

To say the governments of most African states have failed in the areas of governance and development is perhaps not new. The modernization paradigm did not change the status quo neither is globalization going to go very far at resolving the hydra-headed problem confronting the continent of Africa. From Madagascar to Cape Verde, the ever-progressive change in resource mobilization and human development is lacking. The continent houses some of the poorest countries in the world and more are getting poorer by the day, such as 
Central Africa Republic, Somalia, Rwanda, South Sudan etc.

Perhaps these maladies would have been managed to reduce their effects on the continent and its people, if the ruling elite had embraced and engaged positive attitudes and behaviour towards the state and its agency government. Throughout Africa, there are palpable cases of lack of moral tension, prudent management of public resources and integrity of the democratic process. It would seem that corruption is the most lucrative venture or invidious development in the continent (Igbokwe-Ibeto \& Okoye, 2014). In spite, of successive governments' efforts thrown at this problem, it has defied all known remedies to cure this ailment in the body politic. Former President of Zaire now Democratic Republic of Congo, Marshal Mobutu Sese Seko (in Amuwo, 2009) once told a bewildered nation of his own cure for corruption, to wit: "If you steal... do not steal too much at a time. You may be arrested. Steal cleverly little by little. And if you succeed in stealing, invest what you have stolen in the country itself. Those who export what they steal are the enemies of the republic".

This statement may appear bizarre but it shows the extent to which corruption has ravaged public institutions and the failure of orthodox measures to curtail and manage this plague that is ravaging and pauperizing the people. Perhaps, the behaviour and attitudes of both leaders and followers are the biggest obstacles to good governance and development in the continent. One would imagine that every country has its own fair share of corruption in public service but ability to curtail it remains the litmus test. From the point of view of leadership of these countries, self-transformation will certainly go a long way in reducing its occurrence and effects on the populace.

What then are the indicators of governance and development that need to be addressed? It is important to state from the on-set that governance has technocratic, social and political elements. It is necessary for all to work together, because the importance of states that are both efficient and effective in discharging their responsibilities cannot be overemphasized. Key elements that makes for good governance include but not restricted to these: consensual political goals, political participation and political accountability. Also, there is need to address the following:

- Deepen democracy;

- Reversing what negative globalization stands for;

- Emphasis on social governance;

- Structural transformation;

- Better funding of the governance and development agenda; and

- Arresting the debt peonage in Africa.

There is enormous sense in seeking to expand the democratic space in Africa. The crises at hand in Africa were not created in one day and many of them have become embedded in the structure and system of governance in the continent. This makes it necessary for all hands to be on deck to resolve them. There is the need to reconceptualise good governance to embrace 
political rationality among policy makers, reforming state and democratic institutions and expansion of the political space to give non-state actors unrestricted access to channels of expressing themselves.

The pursuit of technocratic governance has led to the neglect of the social concerns of the Africans. Technocratic governance operates with unregulated and undemocratic space in Africa which gives private interests free hands to exploit the people for private ends. Given the present conditions in Africa, the social ingredients of governance should be prioritized. Whilst in the West, issues of unemployment, infrastructural decay, and social upheaval are almost non issues or taken for granted, in Africa they remain intractable and potent.

Structural transformation of the states in Africa is still a prime concern. The internal weaknesses that constitute obstacles to development still persist in most African countries. From Nigeria, South Sudan, Cameroon, Central Africa Republic, to the Democratic Republic of Congo, Malawi, Zimbabwe etc. politics of impunity and authoritarianism still reign supreme in spite of the practice of liberal democracy. In Nigeria, the national question is still unresolved. Crises from all regions and zones of the country to another are hampering the developmental agenda of the state.

The issue of funding of government development is an age long challenge. The situation in Africa is by no means better today than at independence. With over reliance on mono-culture economy, corruption and lack of adequate financial aid from the west, most development programme are either abandoned completely or suspended. Profligacy and lack of fiscal discipline have been the hallmark of African governments. The cost of governance is astronomically high in most sub-Sahara Africa States thereby mortgaging any concerted effort to build capital for development in the continent (Akhakpe, 2014). Efforts to meet the expectations and demands of the people have led to excessive borrowing from within and outside the countries, thereby compounding the debt overhang on the countries.

Consequently, the debt peonage or overhang has become a major barrier to genuine development in Africa. Like a beggar that has no choice, most African countries go to Western governments and world financial institutions to borrow stupendous sums of money which in most cases are frittered away into private pockets in the name of pursuing developmental programmes. Some of these debts will only go to mortgage the interests of future generations of Africans who will have to bear the burden of servicing these loans. In view of the foregoing analysis, how has ICSs help in ameliorating or redressing the present situation in Africa for sustainable socio-economic and politico-administrative development? This is the subject of discussion in the next section of the article.

\section{International Civil Service and Sustainable Development in Africa}

The world is now a global community where national policies and programmes are increasingly being influenced by global forces, one of which is the ICS. This institution has become very important global player because it helps in articulating and aggregating the concerns of member States of the UN-the major regulator of world politics. How are international civil servants expected to intervene in the happenings in members States of the 
organization? Tentatively, the paper can come up with the following suggestions.

International civil servants ICS are found in the secretariat of international organizations. They are of strategic importance in modern 1Os "working for the common interests, rising above all particularism, but respecting the values which each people contribute to humanity (Yi-Chong \& Weller, 2008). In dealing with this subject matter studies have applied the P-A approach to understand how ICSs regarded as agents carry out their functions independently of the influence of members States (the principal). Those who work in IOs need to be properly studied in order to know what the behaviour of agents are.

The question that easily comes to mind is, how IO depicted as agent, is accountable to one or majority of states that make up the UN or its varied organizations or to those seen as political or economic power or those most affected by their actions (Yi Chong \& Weller, 2008). Constructivists justify the active participation of ICS in international politics by treating them as bureaucracies. As such they have authority and autonomy with which they formulate independent roles. By implication, they could have dysfunctional behaviour. Such bureaucratic dysfunction may take the form of failure to carry out their goals. If they are important players in world politics, those that work within them are equally important. ICSs exist to meet collective needs of the "principals". They work behind the scene which obfuscates their contributions to member states' socio-economic and political development. This they can accomplish through their "... power of routine, power to shift, power to initiate, power to shape the direction of debate, technical expertise and bureaucratic skills underpinning their influence.... Their power is further derived from shared values of multilateral cooperation, their expertise and continuity, their capacity to shape the institutions and behaviour of the State involved (Yi Chong \& Weller, 2008).

Furthermore, they can serve as instrument of integration, bringing the world community closer through formulation and implementation of just and equitable policies and programmes that can lift up the human conditions across the globe. They can do this by influencing the organization's behaviour through the use of material and other forms of resources at the disposal of the IO. They can also improve the condition of the world through facilitating multilateral co-operations and bring nations together to solve the common problems that beset humanity. Apart from institutional factors and or formal rules, there are informal factors which may assist ICS's in performing their roles, such as: competence, legitimacy and culture.

However, what comes across to any cursory observe is the persistent deterioration in the condition of the common man in Africa. One would have thought that with the enormous experience and influence ICSs bring into their roles, the conditions in most African States would have improved considerably. But the reverse appears to be the case. Policies and programmes formulated by the UN have not really bridged the gap between the developed and developing countries in the areas of disparity in living conditions in the centre and periphery countries, rampaging roles of killer but preventable diseases and ailments, among others. Some of these problems are outcomes of poor diagnosis and implementation of policies and paradigms from the developed countries. It is interesting to note that in spite, of 
the UN and several international organizations supposedly pursuing collective interests, African countries are still weighed down with seemingly intractable problems.

Ake (1996) has argued and there are empirical evidences to support his views, that democratization in Africa specifically multipartism has not translated into better condition of living for majority of Africans who cannot make their votes count, participate actively in politics due to material and mental poverty and increasingly buffeted by hunger and diseases. The expectations that the adaptation of western liberal democracy will bring about emancipation of Africans and arrest the tide of socio-economic decline has largely been unfulfilled (Akhakpe, 2014). The insistence either subtly or by cajolery that African countries must embrace liberal democracy may not be unconnected with the crisis it has spawned. To Igbokwe-Ibeto, Ewuim, Anazodo, and Osawe (2014); Igbokwe-Ibeto \& Osawe (2013), most countries in Africa appear to have grudgingly accepted the form and not the content of liberal democracy which affects its consolidation processes in the continent.

Similarly, the monetarist economic model being practiced in the world or at least greater part of it, has in many cases caused excruciating pains in countries where it is being practiced. As Igbokwe-Ibeto and Osawe (2013) posits: The neo-liberal monetarist reforms of the adjustment model, with its emphasis on a zero-sum market approach, was (and still) one which from the onset carried huge social cost. Not surprisingly resistance to the implementation of the adjustment programme has come not only among the popular social groups that are the biggest losers from its adoption but among the more privileged groups that profited from the effort at economic liberation.

It is abundantly clear from the submission above that the negative effect on or social cost of the monetarists' regime cuts across social classes and has refused to change its fortune in spite, of suggestions to the contrary from its originators - the World Bank and International Monetary Fund (IMF). This failure of economic reform programmes can be explained at least on two grounds. Is either there is a mis-diagnosis of the problem of African economies that led to wrong prescriptions of its cure or the interest of western capitalism supersedes every other consideration. The question that comes to the fore is, where is the ICSs in all these? What have they been able to do to correct these abnormalities? What factors constrain their moral role in ensuring better life for people all over the world? Attempts are made below to answer these questions.

\section{Challenges Facing International Civil Servants in Sustainable Development}

Both normative and empirical obstacles confront the ICSs in achieving commendable feats in the socio-economic and political development in the world particularly in developing countries.

Financing the UN and its institutions has raised some challenges that bear on socio-economic development of member states. Under the UN charter, all members States are expected to contribute to the regular budget of the UN. But the bulk of its budget is still made up of contributions from developed counties. Taubenfield and Taubenfield in (Akhakpe, 2014) contend that financing the regular budget of the UN has not posed major difficulties but "on 
the other hand, attempts to use the same budgetary system for peace-keeping and proposal that it should be used for re-distributionary income transfer and international welfare support have been bitterly opposed by countries who would be called upon to pay for them. Despite the complaints, the bitterness and the demands of the poor States for development support and the fact of widespread poverty and the debt crisis, the rich countries have refused to be levied for compulsory transfers for the benefit of the poor". In this circumstance it is difficult to see how the ICSs can intervene to change things except perhaps in minor areas where they could apply discretionary actions.

The increase in the UN membership by the attainment of independence of some third world countries has not changed substantially the UN. Though their entrance has made debates in the floor of the UN more robust and put the interests of these new states in the front burner. The heart and soul of the UN and its institutions are still controlled by the big five Security Council members. The Security Council is the core of the UN, with the United States calling the shot. The fact that many years after its formation, no third world country has become a permanent member of the Security Council shows the level to which they are held in the international Community.

The developed World has made a quantum leap in science and technology. This force has been unleashed on the world in both negative and positive directions "creating in man both a new sense of insecurity and terror and a renewed hope that a better life is within his reach (Sohn, 1970). Advances in science and technology have had differential influence on developed and developing countries. In developed countries, nuclear technology they have brought about revolutionary changes in virtually all areas of life in the west. Little of these have trickled into Africa but more in the negative areas of: civil war, hunger, poverty, diseases, and arrested development. Thus, the gap between the rich and poor countries are widening by the day instead of closing. The ICSs have not been able to promote collective attention or integration and cooperation that can bridge this yearning gap.

Also, there is lack of synergy between the UN and its institutions on the one hand and member States on the other in formulating and executing policies. It would seem that some member States prefer unilateral actions and alliances for collective actions. Some secretly supply arms to rebel groups and government in order to achieve their short- term national interests. It is when situation gets out of hand that the UN is called upon to bell the cat or get castigated by the international community (Anazodo, 2012).

It is a truism that there cannot be world peace where "two thirds of the world population is underfed, under-housed and undereducated" (Ezeukwu, 1999; Sohn, 1970). But this situation is exacerbated by the arms race in world politics by the major powers. Money diverted into this endeavour can be used to build sustainable bases for socio development in the world. Unfortunately, some developing countries like Iran and Iraq have joined the race for arms proliferation. It would seem ego and self-interests are being priority in international politics and administration.

Another major constraint facing the role of ICS is the question of geographical representation in the recruitment of staff. This question overtime has become controversial because of the 
issue of imbalance that arose right from the inception of the UN. The first group of staff recruited for service in the UN, came from the Western European and North American countries. This abinitio created an imbalance that has not been corrected. Article 101, paragraph 3, of the UN charter, clearly indicate that in recruiting staff into the UN secretariat "paramount consideration should be given to serving the highest standards of efficiency, competence and integrity" (Graham and Jordan, 1980). Yet, there is nothing to show that staffs from developing countries are less competent and efficient than their counterpart from Europe and North America.

Even the much taunted "highest standards of efficiency, competence and integrity" are not found among majority of staff of the UN and other international organizations. For example, as far back as 1972, a report on personnel problems of the UN Secretariat noted that "a major effort is needed to improve the quality of the secretariat" (Anazodo, 2012). While some of these IOs have excellent staff members in their fold, their personnel policies leave much to be desired because they have done little to attract young intelligent people to replace what one can term "deadwoods", reward excellence and make available opportunities for career development of staff members (Graham and Jordan, 1980).

Further, there are problems created by formal institutional conditions. These include "the organizational arrangements, the mandate, the official procedures, and the source of the budget and distribution of power among member states" (Yi-Chong and Weller, 2008). These factors which determined the amount of authority States can delegate to "IOs, go a long way in determining the ability of ICSs to function as cooperation facilitator" (Yi-Chong and Weller, 2008). Over time ICSs have developed competence, legitimacy and culture which enable them to influence and to some extent determine what goes on in their organizations. Because of these competences they have developed over time, it is difficult for its members States to control them in a manner that they can serve the principal collectively. The more ICSs can deploy these resources - in knowledge, expertise and experience, the less direct control principals (States) can have over them. As is the case with domestic civil servants, controlling the ICSs has become a herculean task to the political masters. How can these impediments to ICS's be addressed and resolved?

\section{International Civil Servants and Sustainable Development in Africa: The Way Forward}

Every system has its own challenges and the UN is not an exception. Like its domestic or national counterpart, ICSs have their own teething problems. But these problems are not insurmountable even if they appear complex and expansive. In what follows, the paper proffers road map for coming out of these "cul de sac".

The world today is still polarized between very wealthy nations and very poor ones. There cannot be peace needed for socio-economic development where some countries feel marginalized and where poverty runs riot in greater part of the world. There is need to bring more nations into the realm of developed countries. The power equation in the world should shift in the direction of expanding the development space where hitherto neglected States would now be allowed to be major players in the system. The security council of the UN 
should be expanded and veto power removed from the so called big five world powers.

Also, the UN and IOs personnel policies should be changed in favour of third world countries particularly in the recruitment of personnel or secretariat staff, in such a manner that geographical spread is respected at all time. This is suggested against the backdrop of perceived injustice against countries of the south-south, Dr. Ngozi Okonjo-Iweala could have been chosen as the head of the World Bank perhaps due to the fact that she is from a third world country.

Governance regime that is in vogue in the world should be discarded. Popular participation in public decision making, respect for the rule of law, transparency, probity and accountability, among others, should be made the building blocks of IOs and the running of their secretariats. With the governance reform emerging from these international organizations specifically the IMF; they should leave by example, by showing how to manage scarce resources at their disposal. Governance should therefore be used to achieve collective interests of member States of the UN rather than that of some selected countries.

Closely related to the above point is the imperative of internal democracy in the UN secretariat and those of its international organizations. As the popular saying goes, "you cannot give what you do not have". If the UN secretariat and others must formulate, implement and advise on democracy, it should have democracy in its internal operations. In doing this, the peculiarity of countries should be taken into consideration. The case where a blanket model is forced down the throat of Member State by its staff is against the logic of specificity and cultural differences which play major roles in the success of any policy or programme. This is important, if socio-economic development in the world is to progress uninhibited.

But all these can only be achieved if there is proper and better funding of the UN secretariat and allied ones by member States. It is clear that many members States of the UN are defaulting in their financial obligations to the organization. Even the more economically buoyant members States are not prompt in their financial duties to the organization. A reverse of this situation will strengthen the operations of the ICSs and boost their morale to pursue the collective interests of member States. The world cannot afford a UN that cannot carry out its socio-economic roles due to scarcity of funds. This will certainly defeat its very essence.

Again, the ICSs must come out of its veil of neutrality and anonymity. If the ICS is to make any appealing impact on the campaign for rapid socio-economic and political development of the world community, the ICSs need to be proactive and interventionist in order to arrest the increasing decline in socio-economic and political development across the globe. The ICSs must connect with the people in order to adequately understand their feelings, yearnings and aspirations. The ICSs still has a lot of convincing to do to assure States from the developing areas of the world that they are not servant of the super powers but of the whole international community. It is not enough to be independent in their operations but reasonably and responsibility discretionary.

It is important that African leaders do something internally to help themselves. They should 
diversify their economies and pursue self-reliance rather than wait for handouts from the West. They should build capital for development rather than pursue kleptocratic politics. International best standards should be embraced and engaged and fiscal discipline should be made their watch-word. But this means the fight against corruption must be carried to the next level. It has been the bane of socio-economic and political development in the continent. But with zero tolerance for corruption, more funds will be available to pursue home grown development models (Akhakpe, 2010).

Better economic integration of African States is required to overcome the perennial crisis in their socio-economic and political programmes. The New Economic Partnership for Africa Development (NEPAD) should be revamped to reflect Africa's culture and history. Ultimately, developmental States are needed in Africa. They must have the "capacity to make and implement policies with relative autonomy, with a view to the engendering socially beneficial goods and values to the greatest number, of the people" (Amuwo, 2009). This States should adapt and harness the power of market forces to serve the social interest of the people.

\section{Conclusion}

The concept of ICS and its role in sustainable development as captured by scholars has been espoused with an attempt at identifying the issues and challenges confronting ICS and the way forward. In addition, searchlight was also beamed on the theoretical exploration for a better understanding of the concepts under analysis. Thus, structural-agency theory has been examined as postulated by scholars. An attempt was also made to establish the nexus between ICS and sustainable development in Africa.

This article argues that the role of ICS in facilitating sustainable development in the global system in general and Africa in particular cannot be overemphasised. To do this at the highest level, it is necessary to have a crop of career staff in the UN secretariat that can pursue collective - interest of its members States. It is no longer debatable if such groups of talented individuals are required in the UN system, but the issue remains how they can be drawn by ensuring geographical spread particularly attracting personnel from developing countries of the world. Luckily, the International Civil Service Commission (ICSC) has been set up to advice the UN general assembly on personnel matters in the organization. But much still have to be done to make this crop of career staff develop the capacity and competences to enable them play their role as cooperation facilitator worldwide. ICSs are expected as a philosophy to pursue the corporate interests of the people rather than their own personal or group interests. This is why they are fondly called servants of the state and the world community respectively. But personal interest will always find its way into what is regarded as the common interest.

Such neglect and abuses have become very suffocating to the recipient of their services to the extent that majority of the world population both at the national and international levels have had to at one time or the other express deep concerns and reservations about their actions and activities particularly as it relates to uplifting the human conditions worldwide. The fact that hunger and diseases, poverty, wars, conflicts, and crises pervade the world politico-administrative system show that they have not been able to rise to the challenges of 
their profession.

\section{References}

Ake, C. (1996), Democratization of disempowerment in Africa. Lagos: Malthouse Press.

Akhakpe, I. (2014), Bureaucracy and good governance, Lagos: Pumark Nig Ltd.

Akhakpe, I. (2010), The United States of Africa and world powers in global economic competition: possibilities and limitation, International Journal of Issues on Development, 2(4).

Amuwo, K. (2009). Globalisation, NEPAD and the governance question in Africa, African Journal Quarterly Online.

Anazodo, R. O., Igbokwe-Ibeto, C. J, Osawe, C. O., \& Nkah, B. C. (2014), Grassroot leadership and sustainable development in Nigeria: Periscoping the impediments and exploring the imperatives, Journal of Sustainable Development in Africa, 16(6), 114-125.

Anazodo, R. O. (2012), International organizations and the world politics: A diagnostic approach, Onitsha: Namandy Publishers Ltd.

Ayeni, A. (2010). Sustainable development through international cooperation in research and education" in L. Popoola and O. Olorunisola (eds.), Contemporary Issues in Sustainable Development: Lessons for and Challenges to Nigeria, Volume III. Ibadan: The Post Graduate School University of Ibadan.

Dibie, R., \& Dibie, J. (2015), Dichotomy of capacity building and youth unemployment in Ethiopia, Africa's Public Service Delivery and Performance Review, 2(3), 25-76. https://doi.org/10.4102/apsdpr.v2i3.59

Ezeukwu, G. (1999), Understanding International Relations, Enugu: CPA and Gold Publishers.

Graham, W., \& Jordan, R. (1980). The International Civil Service: Changing Role and Concepts. New York: Pergarman Press.

Hay, C. (1995). "Structure and agency" in D. Marsh and C. Stoker (eds.), Theory and Methods in Political Science. London: Palmgrove.

Igbokwe-Ibeto, C. J. (2018). Globalisation and sustainable human development, in V. James (ed.), Capacity Building for Sustainable development, London: CABI International.

Igbokwe-Ibeto, C.J. \& Okoye, J.C. (2014), Anti-corruption crusade in Nigeria: More words than deeds. International Journal of Public Policy and Administration Research, 1(2), 47-63.

Igbokwe-Ibeto, C. J., Ewuim, N., Anazodo, R. O., \& Osawe, C. O. (2014). Civil society organizations and democratic consolidation in Nigeria: Issues, challenges and the way forward. Journal of Sustainable Development in Africa, 16(5), 1-13.

Igbokwe-Ibeto, C. J., \& Osawe, C. O. (2013). The paradox of material shortage and 


\section{Macrothink}

Journal of Public Administration and Governance ISSN 2161-7104 2019, Vol. 9, No. 4

democratic consolidation in Nigeria, Review of Public Administration and Management, 2(4), 8-18.

Ibeanu, O. (2008). "Political development" paper presented at the 1998 research training workshop of the centre for research and documentation (CRD), Kano.

Nnoli, O. (2001). Development/underdevelopment: Is Nigeria's developing in O, Nnoli (Ed.), Path to Nigerian Development Dakar: Codesria.

Osaghae, E. (1994). Introduction: Between the individual and the State in Africa: The imperative of development in E. Osaghae (Ed.), Between State and Civil society in Africa. Dakar: Codesria.

Oyeshola, O. (2008). Sustainable development: Issues and challenges for Nigeria. Ibadan: Graphics Nigeria Ltd.

Sohn, L. (1970). "Peaceful settlement of disputes" in A. Holcombe (Ed.), The United Nations: The Next Twenty-Five Years. New York: Ocean Publications Inc.

Taubenfield, H., \& Taubenfield, R. (1970). Financing the United Nations in L. Sohn (Ed.), The United Nations: The Next Twenty-Five Years, New York: Ocean Publications, Inc.

United Nations. (2005). Sustainable development: Managing and protecting our common environment. World Summit Outcome.

Yi-Chong, X. U., \& Weller, P. (2008). To be but not be seen: Deploring the impact of international civil servants, Public Administration: An International Quarterly, 86(1). https://doi.org/10.1111/j.1467-9299.2007.00706.x

\section{Copyright Disclaimer}

Copyright for this article is retained by the author(s), with first publication rights granted to the journal.

This is an open-access article distributed under the terms and conditions of the Creative Commons Attribution license (http://creativecommons.org/licenses/by/4.0/). 